\title{
Geography and the Paris Academy of Sciences: politics and patronage in early 18th-century France
}

\section{Michael Heffernan}

This essay considers the politics and patronage of geography in early-modern France. It examines how the Paris Academy of Sciences, widely acknowledged as the 18th century's pre-eminent scientific society, came to recognise geography as an independent science in 1730 , a century before the establishment of the first geographical societies. Although the Academy was centrally concerned with cartography from its inception in 1666, it initially afforded no official status to geography, which was viewed either as a specialised form of historical inquiry or as a minor component within the hegemonic science of astronomy. The rise of Newtonian mathematics and the associated controversy about the shape of the earth challenged the Academy's epistemological foundations and prompted a debate about the educational and political significance of geography as a scientific practice. The death in 1726 of Guillaume Delisle, a prominent Academy astronomer-cartographer and a popular geography tutor to the young Louis XV, led to a spirited campaign to elect Philippe Buache, Delisle's protégé, to a new Academy position as a geographer rather than an astronomer. The campaign emphasised the social and political utility of geography, though the Academy's decision to recognise this new and distinctively modern science was ultimately facilitated by traditional networks of patronage within the French Royal Court.

Key words 18th-century geography; scientific patronage; Paris Academy of Sciences; French Royal Court

School of Geography, University of Nottingham, Nottingham, NG7 2RD

Email: mike.heffernan@nottingham.ac.uk

Revised manuscript received 5 December 2012

\section{Introduction}

The history of geography can be read as an on-going struggle for recognition and resources within competitive academic environments. The discipline's conceptual remit, educational and research credentials, relations with other fields of inquiry and wider social utility have required continuous elaboration and defence, never more so than in today's academy where funding is determined by audits and competitive assessments that require all subjects to justify their existence. The history of this campaign has previously been examined with respect to geography's recent past, when a modern version of the discipline was established in 19th- and 20th-century schools, universities and geographical societies. This essay provides a deeper history by considering a previously overlooked debate about geography's scientific value during the early 1700 s, a century before the first geographical societies were established in Paris, Berlin and London, and when the organising principles of modern science were still being formulated (Cormack 1997; Withers 2005; Withers and Mayhew 2002).

The debate took place within the Académie Royale des Sciences in Paris, arguably the 'largest, best supported, and most renowned scientific institution' of the 18th century and certainly the model for most continental European scientific societies (McClellan 2001, 7). From its foundation in 1666 to its suppression after the French Revolution, the core membership of the Paris Academy rarely exceeded 45 individuals, each associated with one of the small number of officially recognised sciences. In 1730, a new position was established within this élite community for a specialist in geography. The position was awarded to Philippe Buache, a 30-year-old architect turned cartographer. Drawing on existing histories of French geography (Broc 1974; Godlewska 1999; Konvitz 1987) and on biographical commentaries about the two principal characters in this story, Buache and his mentor Guillaume Delisle (Broc 1971; Dawson 2000; Doublet 1910; Lagarde 1985 1998), this essay examines the systems of social and political patronage that shaped the Academy's debate about the status of geography.

As an inquiry into the nature of geography within a specific institution, this paper responds to recent research in other national contexts that emphasises the multiple character of early modern geography, at once a sensibility cultivated by polite education, a distinctive form of textual and visual representation 
and a practical science in the making, each of these formulations shaped by the creative locations, sites and spaces in which the subject was defined, practised and communicated (Henry 2005; Livingstone 2003; Livingstone and Withers 1999; Withers 2006 2007). These locations include the learned societies that sponsored scientific exploration and survey, the universities and educational establishments where geography was taught and studied, the printing and publishing industries in which geographical writing acquired new, often overtly political registers, and the social, epistolary networks of the 'republic of letters' through which geographical knowledge was exchanged (Elliott 2010; Mayhew 20002004 2005; Ogborn 2007; Ogborn and Withers 2010).

As the Academy's primary objective was to define and promote scientific practice throughout enlightened Europe, its recognition of geography's scientific value has considerable significance for historians of the discipline and for historians of science, not least because this decision involved the first modification of the carefully formulated systems of knowledge specified in the Academy's constitution. What follows is, therefore, an analysis of the politics of scientific classification, inspired in part by Michel Foucault's discussion of the episteme, the modern categories of scientific knowledge established during the 18th century by governing institutions such as the Paris Academy (Foucault 1966 1969; see also Boutier et al. 2006; Withers 1996; Yeo 2003). According to Foucault, the classificatory systems through which we make sense of the world reveal more about the operation of social, cultural and political power than the fundamental categories of nature that these systems supposedly reflect. Epistemic systems of knowledge generate the very conditions of possibility for the analysis, manipulation and control of both nature and society by determining how truth is distinguished from falsehood through the application of scientific criteria and methods of assessment. The argument developed in this paper is that the recognition of geography by the Paris Academy, an organisation established precisely to define scientific practice, was a significant element in the larger politics of epistemic formation (Foucault 1980).

\section{The Paris Academy of Sciences}

The history of the Paris Academy of Sciences has been extensively researched, particularly during the Revolution and the Napoleonic First Empire (Brian and Demeulenaere-Douyère 1996; Crosland 1992; Gillispie 1980 2004; Hahn 1971; Outram 1983; Sturdy 1995). Founded in 1666 by Jean-Baptiste Colbert, Louis XIV's 'contrôleur-général', the Academy was one of several official academies established to continue the work of earlier, independent learned corporations and ensure French cultural and intellectual hegemony across the arts and sciences, a process initiated in 1635 by the establishment of the Académie Française, guardian of the French language (Lux 1989 1990; Roche 1978; Soll 2009; Yates 1947). Unlike the Royal Society, established in London six years earlier as a private, amateur association, the Paris Academy reflected the political culture of Ancien Régime absolutism (Brioist 2007; Lux and Cook 1998). The Crown provided the Academy's accommodation and the salaries of the 41 men elected to its ranks during the 17 th century, an international roll-call that included Giovanni Domenico Cassini, Christiaan Huygens, Jean-Félix Picard and Jean Richer (McClellan 1985; Stroup 1987). These men, arguably science's first professionals, initially conducted their activities at secret, twice-weekly sessions in the Royal Library, with occasional forays to the new Observatory south of the city (Hirschfield 1981). Variously known as La Compagnie, L'Assemblée or 'those who meet in the Royal Library', they produced irregular, anonymous publications (Biagioli 1996, 218; Meynell 1994).

This closed ethos was transformed in 1699 when Abbé Jean-Paul Bignon, the royal librarian and the Academy's president, produced a written constitution that sought to balance academic freedom, public utility and political responsibility while rejecting religious and political dogma (Briggs 1991; Demeulenaere-Douyère and Brian 2002; Stroup 1993; TitsDieuaide 1998). Academicians, henceforth selected by their peers subject to royal approval, were required to pursue research, adjudicate on the originality of scientific inventions and attend the Academy's meetings in the Louvre, where mémoires were discussed in polite exchanges governed by elaborate rules of etiquette and ritual. Election to the Academy provided an entrée to the cafés, salons and theatres of the Parisian 'republic of letters', and was a coveted, often lucrative mark of social and intellectual status. Every six months, proceedings were opened to the public and éloges to recently deceased academicians were read aloud by the permanent secretary, a position occupied by just four individuals during the 18th century: Bernard le Bovier de Fontenelle (whose tenure extended from 1697 to 1740), Jean-Jacques Dortous de Mairan (1741-3), Jean-Paul Grandjean de Fouchy (1744-76) and Nicolas de Condorcet (177693) (Paul 1980). It is a measure of the permanent secretary's prestige that Voltaire lobbied unsuccessfully for the post in 1741 and $1743 .^{1}$

If the Academy was inspired by a Baconian conviction to 'speak truth to power' by offering reasoned guidance to those in authority, its internal organisation suggested a pervasive Cartesianism. While Baconians emphasised inductive reasoning and the unity of 
knowledge, viewing nature as an undifferentiated 'tissue of analogies and reiterated themes' that defied categorisation, the Academy's Cartesians, exemplified by Fontenelle, were more accommodating of specialised, systematic investigation (Daston 1992, 209; Marsak 1959). Unlike the resolutely Baconian Royal Society, which steadfastly refused to categorise its activities and publications, the Academy organised itself into six primary sciences - three mathematical sciences (astronomy, geometry and mechanics) and three physical sciences (anatomy, botany and chemistry). Within these sciences, academicians were divided into three hierarchical classes: pensionnaires (three for each science, plus the secretary and the treasurer), associés (two for each science, plus eight overseas correspondents) and élèves (selected by pensionnaires and re-named adjoints in 1716) (McClellan 1981). The president and vice-president were drawn from ten honoraires who were not required to be actively engaged in science.

The 93 volumes of the Academy's annual publication, the Histoire de l'Académie Royale des Sciences (HARS), published between 1699 and 1790, have been described as 'the century's single most prestigious and important scientific series' (McClellan 2001, 7; see Halleux et al. 2001). Each HARS volume was formally presented to the King by senior academicians, the close relationship with the Crown symbolised by a regularly updated frontispiece image of Minerva holding a portrait of the monarch surrounded by scientific instruments (Schiebinger 1988). Aimed at specialists and the wider public, each $H A R S$ volume was divided into two, separately paginated sections, the longer, second section containing mémoires selected by the Academy's publications committee (McClellan 2003), the shorter, opening section containing brief, often untitled histoires written by the Academy's secretaries to summarise otherwise difficult scientific research. Mémoires were unclassified but histoires were organised into the six primary sciences, plus about a dozen minor subjects, a format that persisted until 1782. The $H A R S$ reveals, therefore, both the nature of the science conducted by the Academy and the organising structures used to communicate with the reading public. It tells us what the Academy did, and what it thought it was doing.

The 3400 HARS mémoires, written by more than 150 academicians and ranging in length from one to 155 pages, are among the earliest scientific articles (Gross et al. 2002). They include reports on pioneering work in all the major sciences (Cohen 1981; Holmes 2003; Salomon-Bayet 1978; Stroup 1990), alongside many examples of what Daston has called the 'preternatural history' of inexplicable 'marvels' and 'curiosities', from 'monstrous' children and deformed adults to talking dogs and curiously long-lived toads (Daston 1991 1998;
Daston and Park 1998; on the Academy's alchemical research, see Jacob 2006, 41-65).

Around 2000 mémoires were classified into the Academy's primary sciences prior to 1782 and these provide a revealing insight into the association's selfimage. Astronomy was easily the dominant science, accounting for a third of all mémoires. This is largely a consequence of the capacious definition of astronomy's remit. Most of the Academy's generously funded overseas expeditions, from Richer's voyages to Cayenne in 1672-3 to Le Gentil's 'transit of Venus' explorations in the Indian Ocean during the 1760s, were reported as exercises in astronomy on the grounds that they involved celestial calculations to determine the dimensions of the earth and the solar system. Reports on the Academy's topographic map-making were likewise defined as astronomy, including the project to construct a national map of France initiated by Jean Picard in 1679 and continued through the 18th century by four generations of the Cassini family of astronomers who oversaw the first triangulation of the Paris meridian published in 1720, the 18-sheet 'carte des triangles' that appeared in 1744 and the 180-sheet edition printed after the Revolution (Pelletier 2002). ${ }^{2}$ So although 16 per cent of the Academy's 18th-century publications focused on cartography, navigation, survey, fixing latitude and longitude, and the size and shape of the earth, more than twice the percentage devoted to the same topics in the Philosophical Transactions of the Royal Society in this period, the Academy's secretaries identified just 52 HARS mémoires $(3 \%)$ as 'géographie', roughly the number defined as algebra, optics and acoustics (Sorrenson 1996).

Astronomy's dominance over geography was repeatedly explained in terms that reveal the Academy's penchant for Jesuit cosmology and Cartesian geometry. As the primary, enabling science, astronomy allowed the 'perfection' of geography, the scientific status of which was constrained by an epistemology that privileged vertical, celestial observation over horizontal, terrestrial measurement. ${ }^{3}$ Geography was the study of the earthly manifestations of astronomical calculation, the music of the spheres played out on the surface of the globe.

\section{The King's Geographer}

The dozen HARS mémoires defined as géographie by Fontenelle prior to 1730 indicate the Academy's limited, essentially historical vision of the subject, a continuation of the humanist commonplace that geography was the 'eye of history' (historiae oculus geographia), the relationship proposed a century earlier by Ortelius (Mayhew 2010) (Table I). Most of these mémoires compared the geographical knowledge of classical civilisations with that of modern science, an 
Table I Mémoires published in the Histoire de l'Académie Royale des Sciences and defined by the Academy's Secretary, Bernard de Fontenelle, as 'géographie', 1699-1730

\begin{tabular}{|c|c|c|c|c|c|}
\hline Year $($ Vol $)$ & Author & Title & Date Read & Mémoire (pp) & Histoire $(p p)$ \\
\hline $1700(4)$ & $\begin{array}{l}\text { Couplet le fils } \\
\text { [Nicolas Couplet } \\
\text { de Tartreaux] }\end{array}$ & $\begin{array}{l}\text { Extrait de quelques lettres écrites de Portugal \& du } \\
\text { Bresil, par M. Couplet le fils, à M. l'abbé Bignon, } \\
\text { Président de l'Académie Royale des Sciences }\end{array}$ & Not presented & $172-8$ & $126-7$ \\
\hline $1702(4)$ & $\begin{array}{l}\text { Cassini } \\
\text { [Giovanni } \\
\text { Domenico] }\end{array}$ & $\begin{array}{l}\text { Comparaison des mesures itineraires anciennes } \\
\text { avec les modernes }\end{array}$ & 28 January & $15-26$ & $80-2$ \\
\hline $1702(4)$ & $\begin{array}{r}\text { Cassini fils } \\
\text { [Jacques] }\end{array}$ & $\begin{array}{l}\text { Reflexions sur la mesure de la Terre, rapportée } \\
\text { par Snellius dans son livre intitulé: } \\
\text { Erastosthenes Batavus }\end{array}$ & 1 March & $60-6$ & $82-3$ \\
\hline $1708(10)$ & $\begin{array}{l}\text { Delisle } \\
\text { [Guillaume] }\end{array}$ & Conjectures sur la position de l'isle de Meroé & 14 November & $365-75$ & 111 \\
\hline $1714(16)$ & $\begin{array}{l}\text { Delisle } \\
\text { [Guillaume] }\end{array}$ & $\begin{array}{l}\text { Justification des mesures des Anciens en } \\
\text { matiere de geographie }\end{array}$ & 11 April & $175-85$ & $80-3$ \\
\hline $1716(18)$ & $\begin{array}{l}\text { Delisle } \\
\text { [Guillaume] }\end{array}$ & Sur la longitude de détroit de Magellan & 4 April & $86-9$ & 65 \\
\hline $1720(22)$ & $\begin{array}{r}\text { Delisle l'ainé } \\
\text { [Guillaume] }\end{array}$ & $\begin{array}{l}\text { Détermination géographique de la situation \& } \\
\text { de l'étendue des différentes parties de la Terre }\end{array}$ & 27 November & $365-84$ & 96 \\
\hline $1721(23)$ & $\begin{array}{r}\text { Delisle l'ainé } \\
\text { [Guillaume] }\end{array}$ & $\begin{array}{l}\text { Determination geographique de la situation et de } \\
\text { l'étendue des pays traversés par le jeune Cyrus, } \\
\text { dans son expédition contre son frere Artaxerxès, \& } \\
\text { par les dix mille Grecs dans leur retraite }\end{array}$ & 23 April & $56-68$ & 779 \\
\hline $1721(23)$ & $\begin{array}{l}\text { Delisle l'ainé } \\
\text { [Guillaume] }\end{array}$ & $\begin{array}{l}\text { Remarques sur la carte de la mer Caspienne, } \\
\text { envoyée à l'Académie par Sa Majesté Czarienne }\end{array}$ & 24 December & $245-54$ & $79-80$ \\
\hline $1725(27)$ & $\begin{array}{r}\text { Delisle l'ainé } \\
\text { [Guillaume] }\end{array}$ & $\begin{array}{l}\text { Examen et comparaison de la grandeur de Paris, de } \\
\text { Londres, \& de quelques autres villes du monde, } \\
\text { anciennes \& modernes }\end{array}$ & 11 April & $48-57$ & 77 \\
\hline $1726(28)$ & $\begin{array}{l}\text { Delisle l'ainé } \\
\text { [Guillaume] }\end{array}$ & $\begin{array}{l}\text { Sur la longitude de l'embouchure de la rivière Saint } \\
\text { Louis, nommée communément le fleuve Misissipi }\end{array}$ & 28 August 1723 & $249-57$ & 46 \\
\hline $1730(32)$ & $\begin{array}{l}\text { de Marain } \\
\text { [Jean-Jacques } \\
\text { Dortous de] }\end{array}$ & $\begin{array}{l}\text { Remarques sur un ecrit de M. Daval, qui se trouve } \\
\text { dans les Transactions Philosophiques de la Société } \\
\text { Royale de Londres, no. 402, an. 1728, touchant la } \\
\text { comparaison qu'a fait M. Delisle, de la grandeur de } \\
\text { Paris avec celle de Londres, dans les Mémoires de } \\
\text { l'Académie Royale des Sciences, an. } 1725 \text {, pag. } 48\end{array}$ & Not presented & $562-74$ & 106 \\
\hline
\end{tabular}

Source: HARS, various volumes.

Note: Titles preserve the inconsistent spellings and accents of the original text.

older tradition of inquiry that had acquired contemporary relevance as a result of the 'querelle' between the 'anciens', who believed the modern world could merely emulate the achievements of classical antiquity, and the 'modernes', who insisted that the 18th century had already surpassed ancient civilisation. This lingering dispute, initiated by the confident modernist claims of Charles Perrault's Le siècle de Louis le Grand (1687) and Fontenelle's Digression sur les anciens et modernes (1688), provided the rationale for the Academy's definition of geography as a specialised form of historical inquiry that demonstrated the superiority of modern science over that of the classical world (DeJean 1997; Fumaroli 2001; Norman 2011; see also Glacken 1973, 389-92; Lowenthal 1985, 74-124).

Eight of these early 18th-century geographical mémoires were presented by Guillaume Delisle, an Academy astronomer elected as 'élève' to Cassini I in February 1702. Delisle was better known as a cartographer, a trade he inherited from his father Claude who began the family map business while employed as a history tutor at the French Court alongside Nicolas Sanson, France's leading 17th-century cartographer. Delisle père had educated several young nobles, including Louis XIV's nephew, Philippe, later duc d'Orléans (Pastoureau 1988). The Delisle atelier, located from 1707 on the Quai de l'Horloge, was renowned for the quality and accuracy of its maps, a stoutly defended reputation that involved intriguing legal disputes with rival map-makers about the provenance and ownership of geographical knowledge (Broc 1970; Dawson 2000, 30-7; Sponberg Pedley 2005, 106-10).

Shortly after his election to the Academy, Delisle was recruited as geography tutor at Court, an engagement Fontenelle later described as 'the most glorious event in his life'. ${ }^{4}$ His position was transformed by the death of Louis XIV in 1715 when the crown passed to the Sun King's five-year old great grandson. The Court, overseen by the aforementioned duc d'Orléans who ruled as Regent until his death in 1723 , moved from 
Versailles to Paris, the orphan Louis XV residing in the Palais des Tuileries, surrounded by his nurses and servants. Delisle and his fellow tutors were now confronted with the task of educating the young King himself, under the watchful eye of his guardian, AndréHercule de Fleury, the Bishop of Fréjus. Delisle's thrice-weekly geography lessons, for which he prepared dozens of maps, proved extremely popular (Antoine 1989, 73-4). Although many of his exercises espoused the traditional historical view of geography, Delisle also introduced contemporary material, notably in his lessons on European rivers. These were printed in a small volume, Cours des principaux fleuves et rivières de l'Europe, the gilt-edged pages of which were typeset by Louis himself in the summer of 1718 in a private workshop constructed so he might learn the rudiments of the book trade (Heffernan 2011). This rare volume traces the routes of 47 European rivers, its child-like prose reinforcing the conceit that the author was Louis rather than Delisle.

The Cours dealt with a central motif in the mythology of Louis's predecessor. The Sun King was often depicted as an Apollonian force of nature in his own right, sweeping across the Rhine at the head of his armies in 1672, uniting the Atlantic and the Mediterranean by the Canal du Midi and re-configuring the rivers around Versailles to ensure the palace's fountains functioned precisely as required (Burke 1994; Mukerji 1997 2009). And yet Delisle's geographical lessons made no reference to Louis XIV's costly and often unsuccessful fluvial adventures, emphasising instead how Europe's rivers formed an integrated natural system for peaceful commercial exchange. By downplaying the Sun King's ability to bend nature to his will, the Cours made a carefully considered political point. The vulnerable young King was presented to the Court as an enlightened monarch-in-the-making, his authority based not on the domination of nature but on reasoned scientific knowledge (Daston 2004).

On 1 July 1718, as Louis was printing the first section of the Cours, Delisle was promoted to 'associé astronome' in the Academy (Sturdy 1995, 205-8). On 24 August, he was designated 'premier géographe du Roi' on a generous annual pension of 1200 livres, a new position that set him apart from the handful of cartographers permitted to use the honorific title 'géographe ordinaire du Roi'. ${ }^{5}$ Delisle's promotions reveal the esteem in which he was held by the Regent, his father's former pupil who believed that science, and perhaps especially geography, could resolve the financial crises caused by Louis XIV's military adventures, a conviction exemplified by the Academy survey he commissioned into the country's mineral resources and his initially enthusiastic acceptance of the experimental policies implemented by the emigré Scottish economist John Law who, as 'contrôleur-général', established the first national bank to use paper currency and an ultimately disastrous joint stock trading company for the Americas (DemeulenaereDouyère and Sturdy 2008; Murphy 1997). With his position now secure, Delisle persuaded 18-year-old Philippe Buache, a trainee architect who had recently won an Académie Royale d'Architecture prize, to work as his assistant. ${ }^{6}$ The two men forged an impressive partnership, generating a mass of new cartography facilitated by Buache's part-time employment at the Naval Ministry's new Dépôt des Cartes, Plans et Journaux, where he helped compile a central archive of maritime maps and charts (Pelletier 2007; Petrella 2009; Petto 2007).

\section{The perfection of geography}

Delisle died of 'apoplexy' on 26 January 1726, struck down on a Parisian street aged 51. ${ }^{7}$ He left a widow, Marie, and nine-year-old daughter, Charlotte. Marie now assumed centre stage, revealing a commercial ambition sadly lacking in her cerebral husband and an impressive understanding of the rococo world of courtly patronage, nepotism and venality (Doyle 1996; Petrovich 1999; Petto 2009; Terrall 1995). On 4 February 1726, she wrote to Bignon, her late husband's close friend now restored as Academy president, seeking his intervention with the Comte de Maurepas, the Academy's youthful vice president and the secretary of the Maison du Roi who had overseen Delisle's promotions in 1718 (Darnton 2010, 31-6). Bignon was entreated to

bring to the attention of the Court the pain of a family afflicted with the loss of its leader, one who did not leave matters in a state one would have wished for but, if I dare say so, in a most pitiable condition. Assistance is given on a daily basis to unfortunate widows of those who have served the State and in my case, my husband had the honour to work usefully for the King and the State. He has even left several very interesting works, all ready for publication, which will never appear unless I receive assistance. ${ }^{8}$

A 400-livre annual pension was agreed on the assumption that Delisle's workshop and valuable copperplates could be sold. But Marie was determined to continue the family business with Buache's support, though his services were in demand elsewhere. Her main rival was Delisle's ambitious younger brother, Joseph-Nicolas, who had been elected to the Academy as 'élève astronome' in 1714. The younger Delisle had been invited by Peter the Great to direct the new observatory in St Petersburg and hoped to recruit Buache as his assistant (Appleby 2001; Chabin 1996; Schulze 1985). ${ }^{9}$ Marie wrote to Bignon on 10 March, insisting Buache's constitution would not tolerate 'the temperature of a country that only those who are born there can bear'. ${ }^{10}$ Bignon, by now convinced that 
Buache was Delisle's natural replacement, persuaded Maurepas to block the appointment.

On 16 March, Bignon wrote at length to Maurepas suggesting a new Academy position in geography. When preparing the 1699 constitution, Bignon claimed to have assumed that 'the astronomers of this Academy would give particular application to Geography'. This had failed to materialise, despite the best efforts of Delisle, an astronomer who became 'the most famous geographer in the universe'. According to Bignon, 'experience shows these two sciences cannot be combined in the same person to the level of perfection that each demands' because both require specialist, timeconsuming attention. This was the primary reason, Bignon revealed, why Delisle, 'despite all his abilities as a geographer', had never been promoted to pensionnaire status as an astronomer. His pension as 'premier géographe du Roi' had been offered 'in place of a pension from the Academy and in recompense for his extensive works'.

These reflections prompt the thought that it would be very useful to establish in the Academy some recompense for geographers who are under the control of astronomers; and this establishment would be still better at present since the late M. Delisle having left a prodigious number of memoires and collections to assure the perfection of geography, that those who would be admitted into the Academy under the title of geographer would be able to benefit from these resources to complete what premature death prevented the late M. Delisle from achieving in the manner in which he would have wished. ${ }^{11}$

Bignon's proposal met with predictable resistance from Cassini II, who suggested his cousin and fellow astronomer Giacomo Filippo Maraldi as Delisle's replacement. Maraldi, already a prominent member of the Academy with almost 90 HARS mémoires to his name, including the annual meteorological reports, was ideally qualified and a licence awarding him a 1000livre pension and the title 'géographe ordinaire du Roi' was issued on 11 May 1726. ${ }^{12}$ Although Maraldi's position was inferior to that of his predecessor, whose status as 'premier géographe' expired with him, the decision to nominate another astronomer as Delisle's replacement at Court suggests a scepticism about geography's potential as an independent science. In his otherwise celebratory éloge to Delisle, Fontenelle expressed this view with characteristic condescension, gently mocking geographers as dogged artisans who undertook the necessary but tedious scrutiny of navigation logs and travel accounts: 'What a boring, and fatiguing discussion! It really is necessary to be a born Geographer to be engaged in this. ${ }^{13}$

Bignon's campaign received a warmer reception in other quarters. In his spirited defence of the Academy's subvention, threatened by austerity measures introduced when Cardinal Fleury assumed full ministerial powers in
1726, René-Antoine Ferchault de Réaumur, the Academy's leading naturalist, stressed the social utility of previously unrecognised sciences, including geography without which he claimed commerce, navigation, national defence, and even safe and reliable travel would be impossible (Brian 1994, 83-7; Maindron 1888, 95-100). ${ }^{14}$ Encouraged by Réaumur, Bignon wrote to Maurepas in March 1728, enclosing a report prepared several months earlier by Marie and a family friend, Nicolas Fréret. This outlined Delisle's work-in-progress at the time of his death and identified Buache as the only person who 'by his natural abilities, and by the knowledge that he has of Monsieur Delisle's principles, would be able to conserve and even perfect Geography'. ${ }^{15}$ In his covering letter, Bignon suggested promoting Buache to 'géographe ordinaire du Roi' and converting Marie's allowance into a 1200 -livre pension in his name. The King should then sponsor a marriage between Buache and 11-year-old Charlotte, binding Buache to a strategically important family business. This would

rescue the family of a scholar who worked only for the utility of the Nation and for the glory of the sciences throughout his life, as one more concerned with the advancement of Geography than his own interests. ${ }^{16}$

A licence specifying these terms was issued to Buache on 20 May 1728, and the title 'premier géographe du Roi' was revived for him shortly afterwards. ${ }^{17}$ Buache's marriage to Charlotte took place a few weeks later, the certificate signed in the presence of the King (Dawson 2000, 81). When Maraldi died on 1 December 1729, the way was clear for Buache to replace Delisle in the Academy as a geographer rather than an astronomer. ${ }^{18}$ To ensure his selection, Buache wrote a detailed report to Maurepas on his work at the Dépôt des Cartes, Plans et Journaux. ${ }^{19}$ On 22 May 1730, the Academy announced the new position of 'adjoint géographe', the first modification to its 1699 constitution, and Buache's nomination was confirmed on 10 June. ${ }^{20}$

\section{'A new career for geography'}

Buache's early career as an academician was inauspicious. He published just four mémoires during the 1730s and 1740s: a discussion of a Delisle map showing the travels of Alexander the Great, an account of a new compass, and two reports on the 1740 floods (Table II). ${ }^{21}$ These represented a significant departure from Delisle's historical-educational approach, but drew no comment from the Academy secretaries, Fontenelle and Dortous de Mairan, neither of whom seemed willing to re-consider the scope of geography, despite the decision to recognise its separate status.

Buache's hesitant start may have been due to personal difficulties. Charlotte, by then pregnant, died in late 1730 , provoking anguished guilt. ${ }^{22}$ Determined 
Table II Buache's contributions to the Histoire de l'Académie Royale des Sciences, 1731-1767

\begin{tabular}{|c|c|c|c|c|}
\hline Year (Vol.) & Title & Date read & Mémoire (pp) & Histoire (pp) \\
\hline $1731(33)$ & $\begin{array}{l}\text { Recherches géographiques sur l'étenduë de l'empire d'Alexandre, \& } \\
\text { sur les routes parcourües par ce Prince dans ses différentes } \\
\text { expéditions. Pour servir à la carte de cet empire, dressées } \\
\text { par le feu Delisle, pour l'usage du Roy }\end{array}$ & 4 April & $110-23$ & 60 \\
\hline $1732(34)$ & $\begin{array}{l}\text { Construction d'une nouvelle boussole, dont l'aiguille donne } \\
\text { par une seule \& même opération, l'inclination \& la déclinaison } \\
\text { de l'aimant, avec plus de précision \& plus de facilité }\end{array}$ & 23 April & $377-84$ & None \\
\hline $1741(43)$ & $\begin{array}{l}\text { Observations sur l'étendue \& la hauteur de l'inondation } \\
\text { du mois de Décembre } 1740\end{array}$ & 7 January & $335-7$ & None \\
\hline $1742(44)$ & Exposé d'un plan hydrographique de la ville de Paris & 26 May & $371-8$ & None \\
\hline $1752(54)$ & $\begin{array}{l}\text { Essai de géographie physique où l'on propose des vûes générales } \\
\text { sur l'espèce de charpente du globe, composée de chaînes de } \\
\text { montagnes qui traversent les mers comme les terres; avec quelques } \\
\text { considerations particulières sur les différens bassins de la mer, \& } \\
\text { sur sa configuration intérieure }\end{array}$ & 15 November & $399-416$ & $117-24$ \\
\hline $1753(55)$ & $\begin{array}{l}\text { Parallèle des fleuves des quatre parties du monde, pour servir à } \\
\text { déterminer les hauteurs des montagnes du globe physique de la } \\
\text { terre, qui s'exécute en relief au dôme de Luxembourg }\end{array}$ & 22 December & $586-8$ & $259-71$ \\
\hline $1754(56)$ & $\begin{array}{l}\text { Mémoire sur les différentes idées qu'on a eues de la traversée } \\
\text { de la mer glaciale artique, \& sur les communications ou jonctions } \\
\text { qu'on a supposées entre diverse rivières }\end{array}$ & 13 November & $1-18$ & 133 \\
\hline $1755(57)$ & $\begin{array}{l}\text { Considérations géographiques \& physiques sur les terres } \\
\text { australes \& antarctiques }\end{array}$ & 30 July 1754 & $17-20$ & None \\
\hline $1755(57)$ & $\begin{array}{l}\text { Mémoire contenant les raisons d'une nouvelle disposition de } \\
\text { mappemonde, pour étudier l'histoire, sur-tout des premières } \\
\text { peuplades, comme des anciens voyages, jusqu'au temps des } \\
\text { grandes navigations des Européens occidentaux }\end{array}$ & 6 September & $526-30$ & $121-4$ \\
\hline 1757 (59) & $\begin{array}{l}\text { Observations géographiques et physiques, où l'on donne une } \\
\text { idée de l'existence de terres antarctiques, \& de leur mer glaciale } \\
\text { intérieure; avec quelques remarques sur un globe physique en relief, } \\
\text { d'un pied de diamètre, qui sert de modèle pour celui de neuf pieds }\end{array}$ & 12 November & $190-203$ & 143-4 \\
\hline $1764(66)$ & $\begin{array}{l}\text { Observations géographiques sur les îles de France \& de Bourbon, } \\
\text { comparées l'une avec l'autre }\end{array}$ & 19 December & $1-6$ & $150-2$ \\
\hline 1767 & $\begin{array}{l}\text { Exposé de divers objets de la géographie physique, concernant les bassins } \\
\text { terrestres des fleuves \& rivières qui arrosent la France, dont on donne } \\
\text { quelques détails, \& en particulier celui de la Seine }\end{array}$ & No date & $504-9$ & $110-11$ \\
\hline
\end{tabular}

Source: $H A R S$, various volumes.

Note: Titles preserve the inconsistent spellings and accents of the original text.

to honour his commitment to Marie, he concentrated on his commercial work, re-organising the workshop and opening a new shop on the Quai de la Mégisserie in 1737. After Marie's death in 1745, he successfully challenged her family for control of the company and then married Elizabeth Mirmont, a relative of the architect Robert Pitrou for whom he had previously worked (Sponberg Pedley 2005, 98, 110).

The opportunity to undertake scientific research improved when Michel-Étienne Turgot, the 'prévôt des marchands' of Paris, commissioned Buache to study the city's vulnerability to flooding (Broc 1971, 30; Lagarde 1985, 21). His work on the Seine, eventually extending over three decades, provided data for the two mémoires on the December 1740 floods and the accompanying maps showing the extent and depth of flood waters, illustrations that demonstrated how poor drainage and road design had exacerbated the crisis. Although Buache's mémoires on Newfoundland (1736), France and its seas (1737), the ecclesiastical divisions of France (1743), the equatorial oceans between Africa and the Americas (1745), and the global meridian (1746) were rejected by the Academy's publication committee, mindful of the cost of printing the manuscript maps on which they were based, contemporary descriptions of his innovative bathymetric charts, since lost, suggest he had begun to develop a more ambitious theory of mountain ranges and river basins as the determining physical structures of the globe. ${ }^{23}$

Buache's ideas seem to have been influenced by a bitter dispute within the Academy about the shape of the earth. According to Cassini II's surveys of the Paris meridian, a given measure of latitude in northern France covered a slightly shorter distance than the same measure in the south. This implied the earth was a spheroid elongated at the poles, a discovery that contradicted earlier calculations by Huygens and Newton that suggested the earth was flattened at the 
poles, the latter supplying detailed workings in the third edition of his Principia (1726). Although Joseph-Nicolas Delisle suspected the accuracy of the meridian survey, and may have decided to leave for St Petersburg as a result (Greenberg 1984, 152-3), the contradiction between Cassini's 'ground truth' and Newton's calculations highlighted the Academy's aversion to the theory of gravitational attraction that was sometimes dismissed as a cabalistic, faintly occult idea, less plausible than the Cartesian view that planetary motion was propelled by vortices of invisible matter (Shank 2008).

Newton had several devoted allies among younger academicians, however, and none was more vocal than Buache's near contemporary, Pierre-Louis Moreau de Maupertuis, who used the dispute about the earth's shape to launch a personal campaign against Cassini II (Greenberg 1995; Terrall 2002). Backed by influential friends, including Voltaire, Maupertuis persuaded the Academy and the Naval Ministry to support two expeditions to survey meridian lines in Lapland and Peru to settle the matter. ${ }^{24}$ The polar expedition, led by Maupertuis, Alexis-Claude Clairaut and the Swedish astronomer Anders Celsius, departed in the spring of 1736 and completed its work the following year. ${ }^{25}$ The equatorial expedition, led by Charles-Marie de $\mathrm{La}$ Condamine and Louis Godin, left earlier and continued into the mid-1740s (Safier 2008). Although the Lapland results vindicated Newton, the controversy persisted for some years, sustained by the absence of the Peruvian results and Cassini II's stubborn refusal to admit defeat, even after his son, Cassini de Thury (Cassini III), acknowledged his father's errors (Passeron 1998). ${ }^{26}$

Maupertuis triumphantly presented his results in several forms, La Figure de la Terre (1738) aimed at his scientific colleagues, the anonymous satire Examen désintéressé des différens ouvrages qui ont été faits pour déterminer la figure de la terre (1740) intended for his literary friends (Terrall 2002, 154-60). His most controversial account, published anonymously in 1740, emphasised the importance of his findings for navigation and trade. The title of this work, Élémens de Géographie, was chosen to infuriate Cassini II who had recently published a 640-page volume under the title Éléments d'Astronomie (1740). Élémens de Géographie implied the shape of the earth was a geographical question, too important for a côterie of Academy astronomers whose errors, left uncorrected, would have had disastrous commercial implications (Terrall 2002, 164-8). Although Élémens de Géographie was re-issued under the author's name in 1742 with Academy approval, Maupertuis's behaviour had alienated senior academicians, including some who originally welcomed his evidence. ${ }^{27}$ When he left to direct the Berlin Academy of Sciences in 1745, few mourned his departure, Grandjean de Fouchy's uncharacteristically critical éloge following his former colleague's death in 1759 pointedly remarking that Élémens de Géographie was not a work of geography (Terrall 2002, 231-69, $362) .{ }^{28}$

Buache realised this controversy provided a new rationale for geography within the Academy, though he was anxious not to associate himself too closely with Maupertuis for fear of alienating the Cassinis. The maps he presented to the Academy sought to transcend the dispute, visualising the globe as a malleable, architectonically robust sphere comprised of interlocking river basins divided by mountain chains. This complex surface configuration was more important than the earth's general shape, Buache implied, though no less amenable to scientific analysis.

Buache began to collaborate with younger academicians inspired by similar ideas, specifically Jean-Étienne Guettard, an 'adjoint botaniste' elected in 1743. In February 1746, Guettard delivered a mémoire based on a 'carte minéralogique' prepared by Buache showing a band of underlying chalk across northern France and southern England. ${ }^{29}$ This image, one of the earliest geological maps, caused a stir in the Academy by emphasising how rival nation states shared common subterranean foundations made visible by science. Grandjean de Fouchy saw the implications of this new kind of geography:

Hitherto Geography's sole objective has been to describe the surface of the terrestrial globe, and to mark upon it the different divisions to which it is susceptible, either by reference to the heavens, or by reference to the different limits of Empires that have successively divided it. We have reviewed this year a geographical work of an entirely other kind. It is no longer a question of dividing the different regions of the earth, according to the limits of Empires \& their provinces, but relative to the different materials that they contain within themselves. ${ }^{30}$

Stung by criticism from one of the Academy's rising stars, the botanist Georges-Leclerc de Buffon, the opening volume of whose Histoire naturelle, générale et particulière (1749) rejected the idea of geography as a science of the earth's structural characteristics (Spary 2000), Guettard and Buache produced two further mémoires in 1751 and 1752 identifying mineralogical affinities between France and Egypt and the Americas and Switzerland (Kish 1976; Laboulais 2010). ${ }^{31}$

In November 1752, Buache delivered his most famous mémoire, blending his ideas into a general theory of the earth as a sphere held in shape by interlocking mountain chains that functioned like the beams of a great building, snaking north-south and east -west across land-masses and ocean floors alike, an image that reveals his architectural training as well as the influence of Maupertuis and Guettard. This lecture, delivered in a public session chaired by the Academy's new president, Chrétien-Guillaume de Malesherbes, 
included two maps, one showing (somewhat inaccurately) the undulations of land and sea bed across northern France and southern England, the second a planisphere indicating real and predicted mountain ranges curving across land masses and ocean floors arranged around the North Pole, which was depicted at the centre of a 'mer glaciale'. ${ }^{32}$ The influence of Buache's 1752 mémoire, which later extended into political debates about the role of 'natural' regions in the administrative geography of France, has been examined elsewhere (Broc 1969, 47-70; Débarbieux 2009; Laboulais 2004; Molle 2009; Smith 1969). Suffice to say that the mémoire secured Buache's position in the Academy and opened, in Grandjean de Fouchy's words, 'a new career for Geography'. No longer limited to descriptions of the 'ancient limits of a Kingdom or an Empire that no longer exists', geography had become a science of the earth's dynamic physical characteristics. ${ }^{33}$ Encouraged by this reception, Buache presented new mémoires comparing river basins in different parts of the world as well as a plan, sadly unrealised, for a giant relief globe, almost three metres in diameter, to be constructed under the dome of the Palais de Luxembourg, a model of which he later used in the geography classes he re-established at Versailles in 1755, where his pupils included three future monarchs (Drapeyron 1888). ${ }^{34}$

Buache's success was tainted almost immediately, however, by a damaging controversy involving JosephNicolas Delisle, who had returned from St Petersburg in 1746. On 8 April 1750, Delisle presented a speculative mémoire on the possibilities of a North West passage between Hudson Bay and the Pacific based on unpublished musings by his late brother Guillaume and dubious Russian information, accompanied by a new map by Buache. ${ }^{35}$ Although the mémoire was rejected by the Academy's publication committee, an extended version was published independently in June 1752, provoking an angry reaction from sceptical cartographers in France and Britain (Lagarde 1989; Sponberg Pedley 1992; Williams 2002, 239-86). ${ }^{36}$ Buache's collaboration with Delisle collapsed under this scrutiny as each blamed the other for the errors of which they were both accused. Many of Buache's subsequent publications, in the HARS and elsewhere, were attempts to defend his reputation, his theory used in an increasingly cavalier manner to predict the configuration of unmapped regions in the Arctic, the Antarctic, the Americas and the 'terres australes'. ${ }^{37}$ Although he remained a contentious figure, the controversies with which Buache became associated did not jeopardise, and may even have enhanced, his position within the Academy. Geography's status was certainly bolstered by Buache's public profile. The majority of the 52 $H A R S$ mémoires classified as 'géographie' appeared after Buache had consolidated his position. This was sufficiently secure by 1770 for him to determine the selection of his nephew, Jean-Nicolas Buache de La Neuville, as his successor. ${ }^{38}$

\section{Conclusion}

The archives and publications of the Paris Academy of Sciences provide a unique resource to investigate how geography was defined and recognised as a science in early 18th-century Europe. Geography's scientific potential, exemplified by the works of Guillaume Delisle and Philippe Buache, was promoted by powerful individuals in the Academy and at the French Royal Court who were able to exploit the networks of personal friendship and family allegiances that encircled the King, the power lines of early 18th-century scientific patronage. Buache's initially unconvincing attempts to establish a scientific rationale for geography within the Academy after 1730 were transformed by a larger dispute between Maupertuis and the advocates of Newtonian mathematics on one side, and the dynastic community of Jesuit-trained, Cartesian astronomers led by Cassini II on the other. Maupertuis's victory in this dispute provided an opportunity for Buache to advance geography's case and resulted in a significant re-configuration of the Academy's epistemological structures as cartography, survey and other forms of scientific practice previously defined as astronomy were re-allocated to the new science of geography establishing, arguably for the first time, the conceptual terrain on which the modern discipline would later be enacted.

There was a subtle political agenda lying behind the promotion of geography's scientific value, evident initially in the treatment of nature in Delisle's lessons for the young Louis XV. This reflected a self-consciously enlightened absolutism, different in tone and style from the preceding era of Louis XIV. Where the Sun King's power had been revealed by costly and often futile attempts to dominate nature, his great grandson was to be trained to understand and acknowledge the transcendent power of the physical environment. Geography, as taught by Delisle and promoted by Buache, provided a simple, visually appealing way to communicate to the King, the Court and the wider reading public, the truth of the Baconian aphorism that 'nature to be commanded must be obeyed'. 39 The new science of geography in early 18 th-century France was sustained by its ability simultaneously to reinforce and to critique the structures of power within a changing regime of absolutism.

\section{Acknowledgements}

The advice of the editor, Alison Blunt, and three anonymous referees is gratefully acknowledged. 


\section{Notes}

1 Fontenelle provided the first history of the Academy in his 1708-22 Histoire de renouvellement de l'Académie Royale des Sciences en M.DC.XCIX et les éloges historiques de tous les académiciens morts depuis ce renouvellement 3 Vols, Jean Boudot veuve et fils, Paris.

2 The Cassini dynasty began with Giovanni Domenico (I), recruited in 1669 from the Panzano observatory in Bologna, and continued under his son Jacques (II), grandson César-François Cassini de Thury (III), and great grandson Jean-Dominique (IV). Cassini II's report on the first survey of the Paris meridian appeared as an appendix to the 1718 HARS, published in 1720, as De la grandeur et de la figure de la terre: suites des mémoires de l'Académie Royale des Sciences, Imprimerie Royale, Paris.

3 Cassini I discussed this relationship in an undated late 17th-century lecture that remained unpublished until 1730: De l'origine \& du progrès de l'astronomie, \& de son usage dans la géographie \& dans la navigation, in Mémoires de l'Académie Royale des Sciences depuis 1666 jusqu'à 1699: Tome VIII, La Compagnie des Libraires, Paris 1-54.

4 Fontenelle 1726 Éloge de M. Delisle HARS 28 Histoires [hereafter H]75-84, 82.

5 Archives Nationales [hereafter AN] $\mathrm{O}^{1} 62$ fo. 183 v. 184.

6 Buache, 'Discours sur l'architecture en général, et des parties qui sont nécessaires à former un bon architecte' (1718), in Archives, Académie des Sciences [hereafter AAS], Dossier Buache.

7 Fontenelle 1726 Éloge de M. Delisle, HARS 28 H75-84; AAS, Dossier Delisle.

8 Bibliothèque Nationale de France, Manuscrits Français [hereafter BNF MSF] 22226, fos. 269-70, veuve Delisle to Bignon, 4 February 1726. This letter, in corrected modern French, appears in Dawson $(2000,73)$.

$9 \mathrm{AN} \mathrm{O}^{1} 69$ fos. $184-5$.

10 BNF MSF 22226, fos. 271-2, veuve Delisle to Bignon, 10 March 1726. This letter, in corrected modern French, appears in Dawson $(2000,76)$.

11 BNF MSF 22234 [microfilm 22425], fos. 20v-21, Bignon to Maurepas, 16 March 1726. This letter, in corrected modern French, appears in Dawson $(2000,91)$.

$12 \mathrm{AN} \mathrm{O}^{1} 70$, fo. 145 .

13 Fontenelle 1726 Éloge de M. Delisle HARS 28 H75-84, 77.

14 'Réflexions sur l'utilité dont l'Académie des sciences pourroit être au Royaume, si le Royaume luy donnoit les Secours dont elle a besoin' (late 1726), AAS, Dossier Réaumur, Folder I, of II.

15 BNF MSF 22226, fos. 264-5, Bignon to Maurepas [enclosing report from veuve Delisle and Fréret to Fleury], March 1728.

16 BNF MSF 22226, fos. 265-6, Bignon to Maurepas, March 1728.

17 AN $0^{1} 72$, fo. 175 .

18 Fontenelle 1729 Éloge de M. Maraldi HARS 31 H116-20.

19 BNF Cartes et Plans [hereafter BNF CP], Ge.DD.2334/1, Buache to Maurepas, January 1730.

20 AAS, Dossier Buache. The circumstances of Buache's election were never forgotten, a ribald joke about his arranged marriage to a virgin bride appearing even in his éloge. See Grandjean de Fouchy 1772 Éloge de M. Buache HARS 75 H135-50.

21 Buache wrote to Maurepas on 22 June 1732 requesting money to construct his new compass. BNF MSF 22226, fos. 273-4.

22 BNF MSF 22226, fos. 261-261v, Buache to Bignon, 6 November 1730; BNF MSF 22235, fo. 49v, Bignon to Buache, 6 November 1730.

23 On Buache's unpublished mémoires, see the untitled notes by Dortous de Mairan 1741 HARS 43 H141-2; Dortous de Mairan 1743 HARS 45 H154; Grandjean de Fouchy 1754 HARS 47 H76-80; Grandjean de Fouchy 1746 HARS 48 H107; and AAS Procès-verbaux: table des rapports de l'Académie des Sciences 1699-1793.

24 See, for example, Maupertuis 1733 Sur la figure de la terre et sur les moyens que l'astronomie et la géographie fournissent pour la déterminer HARS 35 Mémoires [hereafter M]153-64 (no date of presentation).

25 Maupertuis $1737 \mathrm{La}$ figure de la terre déterminé par Messieurs de l'Académie Royale des Sciences, qui ont mesuré le degré du méridien au cercle polaire HARS 39 M389-466 (delivered on 13 November).

26 Cassini de Thury 1740 De la méridienne de Paris, prolongée vers le Nord, \& des Observations qui ont été faites pour décrire les frontières du Royaume HARS 42 M276-92 (delivered on 12 November). His full report, an appendix to the $1740 H A R S$ volume, was entitled $L a$ méridienne de l'Observatoire Royal de Paris, vérifiée dans toute l'étendue du Royaume par de nouvelles observations Guérin, Paris.

27 Maupertuis 1742 Éléments de Géographie Martin, Coignard et Guerin, Paris.

28 Grandjean de Fouchy 1759 Éloge de M. Maupertuis HARS 61 H259-76, esp. 268; Grandjean de Fouchy 1742 Élémens de Géographie HARS 44 H113-14.

29 Guettard 1746 Mémoire et carte minéralogique sur la nature \& la situation des terreins qui traversent la France \& l'Angleterre HARS 48 M363-92 (delivered on 19 February).

30 Grandjean de Fouchy 1746 no title HARS 48 H105-8, 105.

31 Buffon 1749 Histoire naturelle, générale et particulière, avec la description du Cabinet du Roi: Tome Premier Imprimerie Royale, Paris 204-28; Guettard 1751 Mémoire sur les granits de France, comparés à ceux d'Égypte HARS 53 M164-210 (delivered on 9 June); Guettard 1752 Mémoire sur la comparaison du Canada avec la Suisse, par rapport à ses minéraux HARS 54 M189-220, 323-60, 452-8 (delivered on 7 June).

32 Carte physique et profil du canal de la Manche et d'une partie de la Mer du Nord, où se voit l'état actuel des profondeurs de la mer and Planisphère physique où l'on voit du pôle septentrional ce que l'on connoit de terres et mers; avec les grandes chaînes de montagnes qui traversent le globe. The handwritten original is in AAS, Dossier Buache.

33 Grandjean de Fouchy 1752 Sur les chaînes de montagnes du Globe terrestre HARS 54 H117-24, 124. Only a proportion of Buache's diverse work appeared in the $H A R S$. His contributions on earthquakes, including a map, since lost, showing 612 places that experienced aftershocks in the wake of the Lisbon earthquake of 
November 1755 and an early attempt to devise a measure of earthquake intensity, were never published, though they are mentioned in BNF MSF 20236-7.

34 Buache's geography lessons, prepared for Louis XV's grandsons, the Duc de Bourgogne, the Duc de Berry (later Louis XVI), the Comte de Provence (later Louis XVIII) and the Comte d'Artois (later Charles X), survive in BNF CP, Ge.EE.92 Explication et usage des cartes dressées pour l'Institution géographique et historique de Mgr. le duc de Bourgogne en 1756; and in the Bodleian Library MSS C21 (252) Explication des Cartes et Découpures presentées pour l'Institution Historique et Géographique de Monseigneur le Duc de Berry (8 Mai 1765). The smaller globe is discussed in Buache's 1757 mémoire and in BNF CP, Ge.FF.13732/I Explication du globe physique en relief présenté au Roi le 6 novembre 1757.

35 The mémoire is discussed in Grandjean de Fouchy 1750 no title HARS $52 \mathrm{H} 142-54$.

36 Joseph-Nicolas Delisle 1752 Explication de la carte des nouvelles découvertes au nord de la Mer du Sud Desaint et Saillant, Paris.

37 See, for example, Philippe Buache 1753 Considérations géographiques et physiques sur les nouvelles découvertes au nord de la Grande Mer, appellée vulgairement la Mer du Sud Ballard, Paris.

38 On his retirement in 1770, Buache's pension was reduced to 600 livres per year. After his death in 1773, this amount was paid to his wife. His nephew, who inherited his titles, was paid a much reduced pension of 500 livres. AN $\mathrm{O}^{1}$ 116, fo. 1140; $\mathrm{AN} \mathrm{O}^{1} 120$ fo. 277.

39 Francis Bacon 1878 [1620] Aphorism III in Novum Organum: Book 1 -Aphorisms Concerning the Interpretation of Nature and the Kingdom of Man Clarendon Press, Oxford 11

\section{References}

Antoine M 1989 Louis XV Fayard, Paris

Appleby J 2001 Mapping Russia: Farquharson, Delisle and the Royal Society Notes \& Records of the Royal Society 52 191204

Biagioli M 1996 Etiquette, interdependence, and sociability in seventeenth-century science Critical Inquiry 22 193-238

Boutier J, Passeron J-C and Revel J eds 2006 Qu'est-ce qu'une discipline? Éditions de l'EHESS, Paris

Brian E 1994 La mesure de l'état: administrateurs et géomètres au XVIIIe siècle Albin Michel, Paris

Brian E and Demeulenaere-Douyère C eds 1996 Histoire et mémoire de l'Académie des Sciences: guide de recherches Éditions Tec \& Doc, Paris

Briggs R 1991 The Académie Royale des Sciences and the pursuit of utility Past and Present 131 38-88

Brioist P 2007 The Royal Society and the Académie des Sciences in the first half of the eighteenth century in Charle $\mathbf{C}$, Vincent $\mathbf{J}$ and Winter $\mathbf{J}$ eds Anglo-French attitudes: comparisons and transfers between English and French intellectuals since the eighteenth century Manchester University Press, Manchester 63-77
Broc N 1969 Les montagnes vues par les géographes et les naturalistes de langue française au XVIIIe siècle Bibliothèque Nationale, Paris

Broc N 1970 Une affaire de plagiat cartographique sous Louis XIV: le procès Delisle-Nolin Revue d'Histoire des Sciences et de leurs Applications 23 141-53

Broc N 1971 Un géographe dans son siècle: Philippe Buache (1700-1773) Dix-huitième Siècle 3 223-35

Broc N 1974 La géographie des philosophes: géographes et voyageurs français au XVIIIe siècle Éditions Ophrys, Paris

Burke P 1994 The fabrication of Louis XIV Yale University Press, New Haven CT

Chabin A-M 1996 Moscovie ou Russie? Regard de JosephNicolas Delisle et des savants français sur les États de Pierre le Grand Dix-huitième Siècle 28 43-56

Cohen A 1981 Music at the French Royal Academy of Sciences: a study in the evolution of musical thought Princeton University Press, Princeton NJ

Cormack L 1997 Charting an empire: geography in the English universities, 1580-1620 University of Chicago Press, Chicago IL

Crosland M 1992 Science under control: the French Academy of Sciences, 1795-1914 Cambridge University Press, Cambridge

Darnton R 2010 Poetry and the police: communications networks in eighteenth-century Paris Harvard University Press, Cambridge MA

Daston L 1991 Marvelous facts and miraculous evidence in early modern Europe Critical Inquiry 18 93-124

Daston L 1992 Classifications of knowledge in the age of Louis XIV in Rubin D L ed Sun King: the ascendancy of French culture during the reign of Louis XIV Folger Shakespeare Library, Washington DC 207-20

Daston L 1998 The nature of nature in early modern Europe Configurations 6 149-72

Daston L 2004 Attention and the values of nature in the Enlightenment in Daston L and Vidal F eds The moral authority of nature Chicago University Press, Chicago IL 100-26

Daston L and Park K 1998 Wonders and the order of nature, 1150-1750 Zone Books, New York

Dawson N-M 2000 L'Atelier Delisle: l'Amérique du Nord sur la table à dessin Sillery, Québec

Débarbieux B 2009 Mountains: between pure reason and embodied experience: Philippe Buache and Alexander von Humboldt in Cosgrove D and della Dora V eds High places: cultural geographies of mountains, ice and science I B Tauris, London 87-104

DeJean J 1997 Ancients against moderns: culture wars and the making of a fin de siècle University Press of Chicago, Chicago IL

Demeulenaere-Douyère $\mathbf{C}$ and Brian $\mathbf{E}$ eds 2002 Règlement, usages et science dans la France de l'absolutisme à l'occasion du troisième centenaire du règlement instituant l'Académie Royale des Sciences (26 janvier 1699) Éditions Tec \& Doc, Paris

Demeulenaere-Douyère $\mathbf{C}$ and Sturdy $\mathbf{D}$ eds 2008 L'Enquête du Régent, 1716-1718: sciences, techniques et politique dans la France pré-industrielle Brepols, Turnhout

Doublet C 1910 Une famille d'astronomes et de géographes Clèdes, Bordeaux

Doyle W 1996 Venality: the sale of offices in eighteenth-century France Clarendon Press, Oxford 
Drapeyron L 1888 Les deux Buache et l'éducation géographique de trois rois de France (Louis XVI, Louis XVIII, Charles X) avec documents inédits Delagrave, Paris

Elliott P 2010 Enlightenment, modernity and science: geographies of scientific culture and improvement in Georgian England I B Tauris, London

Foucault M 1966 Les mots et les choses: une archéologie des sciences humaines Gallimard, Paris

Foucault M 1969 L'archéologie du savoir Gallimard, Paris

Foucault M 1980 Power/knowledge: selected interviews and other writings, 1972-1977 Gordon C ed Pantheon Press, New York

Fumaroli M 2001 La querelle des anciens et des modernes Gallimard, Paris

Gillispie C C 1980 Science and polity in France at the end of the Old Regime Princeton University Press, Princeton NJ

Gillispie C C 2004 Science and polity in France: the Revolutionary and Napoleonic years Princeton University Press, Princeton NJ

Glacken C 1973 Traces on the Rhodian shore: nature and culture in Western thought from ancient times to the end of the eighteenth century University of California Press, Berkeley CA

Godlewska A 1999 Geography unbound: French geographic science from Cassini to Humboldt University of Chicago Press, Chicago IL

Greenberg J L 1984 Degrees of longitude and the earth's shape: the diffusion of a scientific idea in Paris in the 1730s Annals of Science 41 151-8

Greenberg J L 1995 The problem of the earth's shape from Newton to Clairaut: the rise of mathematical science in eighteenth-century Paris and the fall of 'normal' science Cambridge University Press, Cambridge

Gross A, Harmon J and Reidy M 2002 Communicating science: the scientific article from the 17th century to the present Oxford University Press, Oxford

Hahn R 1971 The anatomy of a scientific institution: the Paris Academy of Sciences, 1666-1830 University of California Press, Berkeley CA

Halleux R, McClellan J, Berariu D and Xhayet G 2001 Les publications de l'Académie Royale des Sciences de Paris (1666-1793) Tome I: Description bibliographique Brepols, Turnhout

Heffernan M 2011 Courtly geography: nature, authority and civility in early eighteenth-century France in Daniels S, DeLyser D, Entrikin J N and Richardson D eds Envisioning landscapes, making worlds: geography and the humanities Routledge, London 94-105

Henry J 2005 National styles in science: a possible factor in the Scientific Revolution in Livingstone D N and Withers C W J eds Geography and revolution University of Chicago Press, Chicago IL 43-74

Hirschfield J M 1981 [1957] The Académie Royale des Sciences, 1666-1683: inauguration and initial problems of method Arno Press, New York

Holmes F L 2003 Chemistry in the Académie Royale des Sciences Historical Studies in the Physical and Biological Sciences 34 41-68

Jacob M 2006 Strangers nowhere in the world: the rise of cosmopolitanism in early modern Europe University of Pennsylvania Press, Philadelphia PA

Kish G 1976 Early thematic mapping: the work of Philippe Buache Imago Mundi 38 129-36
Konvitz J 1987 Cartography in France 1660-1848: science, engineering, and statecraft University of Chicago Press, Chicago IL

Laboulais I 2004 Le système de Buache, une 'nouvelle façon de considérer notre globe' et de combler les blancs de la carte in Laboulais I ed. Combler les blancs de la carte: modalité et enjeux de la construction des savoirs géographiques (XVIIIe-XXe. siècle) Presses Universitaires de Strasbourg, Strasbourg 93-115

Laboulais I 2010 Inventorier et cartographier les ressources minérales en France des années 1740 aux années 1830 in Besse J-M, Blais $\mathbf{H}$ and Surun I eds Naissances de la géographie moderne (1760-1860): lieux, pratiques et formation des savoirs de l'espace ENS Éditions, Lyons 155-93

Lagarde L 1985 Philippe Buache, 1700-1773 Geographers: BioBibliographical Studies 9 21-7

Lagarde L 1989 Le passage de nord-ouest et la Mer de l'Ouest dans la cartographie française du 18e. siècle: contribution à l'étude de l'oeuvre de Delisle et Buache Imago Mundi 41 1943

Lagarde L 1998 Philippe Buache: cartographe ou géographe? in Lecoq D and Chambard $\mathbf{A}$ eds Terre à découvrir, terres à parcourir: exploration et connaissance du monde au XIIeXIXe siècles L'Harmattan, Paris 147-66

Livingstone D N 2003 Putting science in its place: geographies of scientific knowledge University of Chicago Press, Chicago IL

Livingstone D N and Withers C W J eds 1999 Geography and Enlightenment University of Chicago Press, Chicago IL

Lowenthal D 1985 The past is a foreign country Cambridge University Press, Cambridge IL

Lux D S 1989 Patronage and royal science in seventeenth-century France: the Académie de Physique in Caen Cornell University Press, Ithaca NY

Lux D S 1990 Colbert's plan for the Grande Académie: royal policy toward science, 1663-67 Seventeenth-Century French Studies 12 177-88

Lux D S and Cook H J 1998 Closed circles and open networks? Communicating at a distance during the Scientific Revolution History of Science 36 179-211

Maindron E 1888 L'Académie des sciences Alcan, Paris

Marsak L M 1959 Bernard de Fontenelle: the idea of science in the French Enlightenment Transactions of the American Philosophical Society NS 49 1-63

Mayhew R J 2000 Enlightenment geography: the political languages of British geography 1650-1850 Palgrave, London

Mayhew R J 2004 Geography books and the character of Georgian politics in Ogborn $\mathbf{M}$ and Withers $\mathbf{C ~ W ~} \mathbf{J}$ eds Georgian geographies: essays in space, place and landscape in the eighteenth century Manchester University Press, Manchester 192-211

Mayhew R J 2005 Mapping science's imagined community: geography as a Republic of Letters, 1600-1800 British Journal for the History of Science 38 73-92

Mayhew R J 2010 Geography as the eye of Enlightenment historiography Modern Intellectual History 7 611-27

McClellan J E 1981 The Académie Royale des Sciences, 1699 1793: a statistical portrait Isis 72 541-67

McClellan J E 1985 Science reorganized: scientific societies in the eighteenth century Columbia University Press, New York

McClellan J E 2001 The mémoires of the Académie Royale des Sciences, 1699-1790: a statistical overview in Halleux R, 
McClellan J, Berariu D and Xhayet G eds Les publications de l'Académie Royale des Sciences de Paris (1666-1793) Tome II: Étude statistique Brepols, Turnhout 7-36

McClellan J E 2003 Specialist control: the Publications Committee of the Académie Royale des Sciences (Paris) 1700-1793 Philadelphia: Transactions of the American Philosophical Society vol 93

Meynell G 1994 The Académie des Sciences at the rue Vivienne, 1666-1699 Archives internationales d'histoire des sciences $4422-7$

Molle F 2009 River-basin planning and management: the social life of a concept Geoforum 40 484-94

Mukerji C 1997 Territorial ambitions and the gardens of Versailles Cambridge University Press, Cambridge

Mukerji C 2009 Impossible engineering: technology and territoriality on the Canal du Midi Princeton University Press, Princeton NJ

Murphy A 1997 John Law: economic theorist and policy-maker Oxford University Press, Oxford

Norman L F 2011 The shock of the ancient: literature and history in early modern France The University of Chicago Press, Chicago IL

Ogborn M 2007 Indian ink: script and print in the making of the English East India Company University of Chicago Press, Chicago IL

Ogborn M and Withers C W J eds 2010 Geographies of the book Ashgate, London

Outram D 1983 The ordeal of vocation: the Paris Academy of Sciences and the Terror, 1793-5 History of Science 21 257-73

Passeron I $1998 \mathrm{La}$ form de la terre, est-elle une preuve de la vérité du système newtonien? in Lecoq $\mathbf{D}$ and Chambard $\mathbf{A}$ eds Terre à découvrir, terres à parcourir: exploration et connaissance du monde au XIIe-XIXe siècles LHarmattan, Paris 129-45

Pastoureau M 1988 Introduction: Nicolas Sanson d'Abbeville in Pastoureau M ed Atlas du Monde 1665 Sand \& Conti, Paris $11-46$

Paul C B 1980 Science and immortality: the éloges of the Paris Academy of Sciences (1699-1791) University of California Press, Berkeley CA

Pelletier M 2002 Les cartes de Cassini: la science au service de l'État et des régions Éditions du CTHS, Paris

Pelletier M 2007 Buache et le Dépôt des Cartes, Plans et Journaux de la Marine in van Gestel-van het Schip P and van der Krogt $\mathbf{P}$ eds Mappae Antiquae: Liber Amicorum Günter Schilder HES \& DG Publishers, Houten 563-78

Petrella M 2009 Guillaume Delisle's Carte du Duché de Bourgogne: the role of central and peripheral authorities in the construction of a provincial territory in France in the early 18th century Journal of Map and Geography Libraries 5 17-39

Petrovich V C 1999 Women and the Paris Academy of Sciences Eighteenth-Century Studies 32 383-90

Petto C M 2007 When France was king of cartography: the patronage and production of maps in early modern France Lexington Books, Lanham MD

Petto C M 2009 Playing the feminine card: women of the early modern map trade Cartographica 44 67-81

Roche D 1978 Le siècle de Lumières en province: Académies et académiciens provinciaux, 1680-1789 2 vols Éditions EHESS, Paris
Safier N 2008 Measuring the new world: Enlightenment science and South America University of Chicago Press, Chicago IL

Salomon-Bayet C 1978 L'institution de la science et l'expérience du vivant: méthode et expérience à l'Académie Royale des Sciences, 1666-1793 Flammarion, Paris

Schiebinger L 1988 Feminine icons: the face of early-modern science Critical Inquiry 14 661-91

Schulze L 1985 The Russification of the St Petersburg Academy of Sciences and Arts in the eighteenth century British Journal for the History of Science 18 305-35

Shank J B 2008 The Newton wars and the beginning of the French Enlightenment University of Chicago Press, Chicago IL

Smith C T 1969 The drainage basin as an historical basis for human activity in Chorley $\mathbf{R} \mathbf{J}$ ed Water, earth and man: a synthesis of hydrology, geomorphology and socio-economic geography Methuen, London 101-10

Soll J 2009 The information master: Jean-Baptiste Colbert's secret state intelligence system University of Michigan Press, Ann Arbor MI

Sorrenson R 1996 Towards a history of the Royal Society in the eighteenth century Notes \& Records of the Royal Society 50 29-46

Spary E 2000 Utopia's garden: French natural history from Old Regime to Revolution University of Chicago Press, Chicago IL

Sponberg Pedley M 1992 Bel et Utile: The Work of the Robert de Vaugondy Family of Mapmakers The Map Collector, Tring

Sponberg Pedley M 2005 The commerce of cartography: making and marketing maps in eighteenth-century France and England University of Chicago Press, Chicago IL

Stroup A 1987 Royal funding of the Parisian Académie Royale des Sciences during the 1690s Philadelphia: Transactions of the American Philosophical Society vol 77

Stroup A 1990 A company of scientists: botany, patronage and community at the seventeenth-century Parisian Royal Academy of Sciences University of California Press, Berkeley CA

Stroup A 1993 Science, politique et conscience aux débuts de l'Académie royale des sciences Revue de synthèse 114 423-53

Sturdy D J 1995 Science and social status: the members of the Académie des Sciences, 1666-1750 The Boydell Press, Woodbridge

Terrall M 1995 Gendered spaces, gendered audiences: inside and outside the Paris Academy of Sciences Configurations 3 207-32

Terrall M 2002 The man who flattened the earth: Maupertuis and the sciences of the Enlightenment University of Chicago Press, Chicago IL

Tits-Dieuaide M-J 1998 Les savants, le société et l'État: à propos du 'renouvellement' de l'Académie royale des sciences (1699) Journal des Savants 1 79-114

Williams G 2002 Voyages of delusion: the Northwest Passage in the Age of Reason HarperCollins, London

Withers C W J 1996 Encyclopaedism, modernism and the classification of geographical knowledge Transactions of the Institute of British Geographers NS 21 275-98

Withers C W J 2005 Geography, science and the Scientific Revolution in Livingstone D N and Withers C W J eds Geography and revolution University of Chicago Press, Chicago IL 75-105

Withers C W J 2006 Eighteenth-century geography: texts, practices, sites Progress in Human Geography 30 711-29 
Withers C W J 2007 Placing the Enlightenment: thinking geographically about the age of reason University of Chicago Press, Chicago IL

Withers C W J and Mayhew R J 2002 Rethinking 'disciplinary' history: geography in British universities, c. 1580-1887 Transactions of the Institute of British Geographers NS 27 11-29
Yates F A 1947 The French Academies of the sixteenth century Warburg Institute, London

Yeo R 2003 Classifying the sciences in Porter $\mathbf{R}$ ed The Cambridge history of science. Vol. 4: The eighteenth century Cambridge University Press, Cambridge 239-66 